\title{
Polymorphism of the SRD5A2 gene and the risk of prostate cancer
}

\author{
RÓBERT DUŠENKA ${ }^{1}$, ROMAN TOMAŠKIN ${ }^{2}$, JÁN KLIMENT ${ }^{2}$, DUŠAN DOBROTA ${ }^{1}$, \\ SVETLANA DUŠENKOVÁ ${ }^{2}$, MARTA VILČKOVÁ ${ }^{1}$ and MONIKA KMEŤ'OVÁ SIVOŇOVÁ ${ }^{1}$ \\ ${ }^{1}$ Department of Medical Biochemistry, Jessenius Faculty of Medicine; ${ }^{2}$ Department of Urology, \\ Jessenius Faculty of Medicine and UHM, Comenius University in Bratislava, Martin 03601, Slovakia
}

Received September 9, 2013; Accepted May 2, 2014

DOI: $10.3892 / \mathrm{mmr} .2014 .2621$

\begin{abstract}
Androgens are actively involved in the development of the prostate gland and appear to be essential for prostate carcinogenesis. The product of the SRD5A2 gene, membrane-bound steroid 5- $\alpha$-reductase, type II enzyme, is key in testosterone metabolism. The present study explored the association between the SRD5A2 V89L gene polymorphism and the risk of developing prostate cancer. The study cohort consisted of 456 male Slovak patients, including 260 cases with histologically confirmed prostate cancer and 196 age-matched controls without any clinically suspected infections of the prostate. Polymerase chain reaction-restriction fragment length polymorphism analysis was used to detect the SRD5A2 polymorphism on codon 89 . Odds ratios (ORs) with corresponding $95 \%$ confidence intervals (95\% CIs) for different allele variants were calculated in order to determine the association between the SRD5A2 V89L gene polymorphism and prostate cancer. The distribution of V89L variants in the control group was consistent with the Hardy-Weinberg equilibrium $\left(\chi^{2}\right.$ test, $\left.\mathrm{P}=0.266\right)$ with a significant deviation in the case group ( $\chi^{2}$ test, $\left.\mathrm{P}=0.04\right)$. However, no association between the SRD5A2 polymorphism and an increased risk of developing prostate cancer was identified. When the wild type VV variant was used as a reference, the ORs for different allele variants ranged from 1.11 (95\% CI 0.66-1.87, $\mathrm{P}=0.70$ ) for the LL genotype to 0.99 (95\% CI 0.68-1.46, $\mathrm{P}=0.99$ ) for the $\mathrm{LL}+\mathrm{VL}$ genotypes. No particular allele variant was identified to exhibit an increased capacity to promote the development of highly aggressive prostate cancer (Gleason $\geq 7$ ) or induce carcinogenesis at an earlier onset ( $<65$ years of age). It was confirmed that in the population studied, the SRD5A2 V89L polymorphism was not associated with the risk of prostate cancer and SRD5A2 was not shown to be a key gene involved in prostate cancer development. Published data indicate that a combination of multiple genetic changes are required
\end{abstract}

Correspondence to: Dr Róbert Dušenka, Department of Medical Biochemistry, Jessenius Faculty of Medicine, Comenius University in Bratislava, Malá Hora 4, Martin 03601, Slovakia

E-mail: rdusenka@gmail.com

Key words: SRD5A2, gene polymorphism, prostate cancer for prostate cancer development, rather than a single gene change. Therefore, it was hypothesized that high-throughput genotyping may be more effective than single nucleotide polymorphism detection.

\section{Introduction}

Prostate cancer is the most common type of cancer in males and second most common cause of cancer-related mortality with an increasing incidence worldwide (1). Despite the fact that Slovakia has a higher incidence of prostate cancer than other countries in the Central and Eastern Europe, it is classified as a country with an intermediate incidence of prostate cancer. In the year 2003, 1,130 cases of prostate cancer were diagnosed in Slovakia, which represents a raw incidence of 43.3/100,000 males and an age-standardized rate (ASR) of $33.9 / 100,000(2,3)$. The incidence of prostate cancer in Slovakia increased with an ASR of 14.6, 14.5 and 33.9/100,000 in the years 1968, 1980 and 2003, respectively.

The most well-recognized risk factors for prostate cancer development are age, geographic origin/ethnicity and family history of the disease (1). The known modulating susceptibility factors of prostate cancer are diet and lifestyle $(4,5)$. Other predisposing risk factors for prostate cancer may be considered, including heredity (genetics), hormonal influences and environmental factors (6-8).

Androgens, testosterone and dihydrotestosterone (DHT) are actively involved in the growth and development of the prostate, and appear to be essential for carcinogenesis in the prostate gland (9). In total, 80-90\% of prostate cancers are dependent on androgens at initial diagnosis, and endocrine therapy of prostate cancer is directed towards the reduction of serum androgens and inhibition of the androgen receptor $(10,11)$. It has been hypothesized that variation in the genes involved in androgen biosynthesis and metabolism may be risk factors for prostate cancer (12). One of these genes is steroid-5- $\alpha$-reductase, which irreversibly catalyzes the conversion of testosterone to its more active and most potent androgen DHT $(13,14)$.

A total of two steroid-5- $\alpha$-reductases expressed in the human prostate have been identified and steroid-5- $\alpha$-reductase, type II is the predominant isoenzyme that is encoded by the SRD5A2 gene. Subsequent to catalysis of this enzyme, the binding affinity of DHT to an androgen receptor is five times higher compared with that of testosterone (13). It 
has been demonstrated that young Japanese males have a lower steroid-5- $\alpha$-reductase activity compared with young Caucasian-American and African-American males (15), and the DHT:testosterone ratio was highest in African-Americans, intermediate in Caucasians and lowest in Asian-Americans, corresponding to the respective risk of developing prostate cancer in these groups $(16,17)$. Montgomery et al (18) demonstrated the downregulation of SRD5A2 mRNA in castration-resistant metastatic prostate cancer tissue. This finding is consistent with the hypothesis that testosterone may be equally as important as DHT in promoting the aggressive behavior of advanced prostate cancer cells.

The SRD5A2 gene is located on the short (p) arm of chromosome 2 at position 23. It spans over $40 \mathrm{Kbp}$ of genomic DNA and contains 5 exons and 4 introns (19). Several polymorphisms within the SRD5A2 gene have been identified (20). One of the most highly polymorphic, contested and investigated is a single nucleotide polymorphism that replaces the more frequently encountered valine (V) with a leucine (L) residue at amino acid position 89 (V89L, rs523349) $(21,22)$. Experiments with cloned and expressed human SRD5A2 isoforms reported significant differences in their $\mathrm{K}_{\mathrm{M}}$ and $\mathrm{V}_{\max }$ values (23). The LL genotype tends to have decreased enzyme activity (21). In certain studies, this genotype was associated with lower androgen levels $(22,24)$; however, in others this was not observed (25). Controversies remain regarding the association of this polymorphism with the risk of prostate cancer. Studies have reported a decreased risk of prostate cancer associated with the LL genotype $(26,27)$, an increased risk with the LL genotype $(28,29)$ or no association with risk and this genotype $(17,30)$.

Given the importance of the SRD5A2 gene in androgen production and the conflicting epidemiological data regarding the $S R D 5 A 2$ polymorphism as a risk factor for prostate cancer, a case-control study of the association between the SRD5A2 V89L polymorphism and the risk of prostate cancer was conducted. The hypothesis of the association between this polymorphism and tumor grade and disease onset within the study population was also investigated.

\section{Patients and methods}

Study population. A case-control study was conducted that included 260 patients with histologically verified prostate cancer and 196 age-matched control patients who visited the Department of Urology in the University Hospital Martin (Martin, Slovakia) between May 2005 and June 2010. The mean age of the patients was 63.6 years for the prostate cancer cases and 62.3 years for the controls. All the cases and controls were Caucasians. In the prostate cancer group $(n=260), 83$ patients $(31.9 \%)$ had a Gleason score $<7$ (histological grading system referring to the cancer aggressiveness in clinical setting) (31) and 159 patients (61.2\%) had a Gleason score $\geq 7$. In the remaining $18(6.9 \%)$ cases the Gleason score was not recorded and these patients were excluded from the prostate cancer subgroup analysis. Subjects were recruited to participate in the study if they met the inclusion and exclusion criteria.

Patients with histologically proven prostate cancer (in a biopsy specimen or radical prostatectomy specimen) regard- less of the pathological stage were enrolled in the study. Patients with the presence of any other type of cancer or major urological pathology, or patients who had a first-degree relative (brother or father) with a confirmed diagnosis of prostate cancer were excluded.

In the control group, age-matched healthy men without any clinically suspected infection of the prostate, benign prostate hyperplasia, benign prostate enlargement or prostatitis were included. The presence of prostate cancer was clinically excluded by a negative digital rectal examination finding and prostate-specific antigen (PSA) serum level within the normal age specific range (32). Controls that had a first-degree relative (brother or father) with a confirmed diagnosis of prostate cancer were excluded.

The basic characteristics of the study population are described in Table I. The present study was approved by the Ethical Board of Jessenius Faculty of Medicine, Comenius University (Martin, Slovakia) and informed written consent was obtained from all participants prior to the study.

DNA extraction. In order to collect $5 \mathrm{ml}$ of blood from all the study participants a standard venipuncture was used (ethylenediaminetetraacetic acid was added as an anticoagulant). Briefly, selected polymorphisms were investigated in isolated DNA from $5 \mathrm{ml}$ peripheral blood which was collected into heparinized test tubes using ethylenediaminetetraacetic acid (EDTA) and were stored at $-20^{\circ} \mathrm{C}$ until analysis. Genomic DNA from peripheral blood leukocytes was isolated after digestion with proteinase $\mathrm{K}$ by extraction with organic solvents (phenol, chloroform isoamylalcohol) and precipitation using ethanol. Blood samples were lysed using lysing solution (0.77 $\mathrm{M} \mathrm{NH}_{4} \mathrm{Cl}, 0.046 \mathrm{M} \mathrm{NaHCO}_{3}, 0.01 \mathrm{M}$ EDTA) and a sediment was placed into SE solution $(0.075 \mathrm{M} \mathrm{NaCl}$, $0.025 \mathrm{M}$ EDTA) and incubated at $55^{\circ} \mathrm{C}$ for three hours (or incubation at $37^{\circ} \mathrm{C}$ overnight). Isolation continued with a standard phenol/chloroform methodology (33) was used to extract genomic DNA, which was stored at $-20^{\circ} \mathrm{C}$ until further genotype analysis.

Genotyping. Restriction fragment length polymorphism analysis polymerase chain reaction (RFLP-PCR) was used to detect the SRD5A2 polymorphism on codon 89 according to the study by Cicek et al (34). The PCR reaction mixture $(25 \mu \mathrm{l})$ included $100 \mathrm{ng}$ genomic DNA, $200 \mu \mathrm{mol} / 1$ deoxynucleoside triphosphates, 1 unit of Taq polymerase in 10X PCR buffer [composed of $16.6 \mathrm{mmol} / 1\left(\mathrm{NH}_{4}\right) 2 \mathrm{SO}_{4}$ and $20.0 \mathrm{mmol} / 1$ $\left.\mathrm{MgCl}_{2} ; \mathrm{pH} 8.8\right]$ and $25 \mathrm{pmol}$ of each of the SRD5A2 primers (SRD5A2-F, 5'-TGG CCT TGT ACG TCG CGA AG-3' and SRD5A2-R, 5'-AGC AGG GCA GTG CGC TGC ACT-3'). For amplification, PCR was used with the following steps: Initial denaturation for $5 \mathrm{~min}$ at $94^{\circ} \mathrm{C}, 35$ cycles at $94^{\circ} \mathrm{C}$ for $45 \mathrm{sec}$, $62^{\circ} \mathrm{C}$ for $1 \mathrm{~min}$ and $72^{\circ} \mathrm{C}$ for $1 \mathrm{~min}$. The final elongation step was performed at $72^{\circ} \mathrm{C}$ for $10 \mathrm{~min}$. Each PCR product (261 bp) was digested at $37^{\circ} \mathrm{C}$ for $16 \mathrm{~h}$ by the restriction enzyme $R s a \mathrm{I}$ (5 units, Fermentas, Denmark) in order to determine the presence of the V89L variant (9), separated by the Microchip Electrophoresis system for DNA/RNA Fragment Analysis MCE $^{\circledR}-202$ MultiNA (Shimadzu, Japan). The common SRD5A2-89V allele retained the $R s a \mathrm{I}$ restriction site at the polymorphic region and generated 21-, 62- and 169-bp frag- 


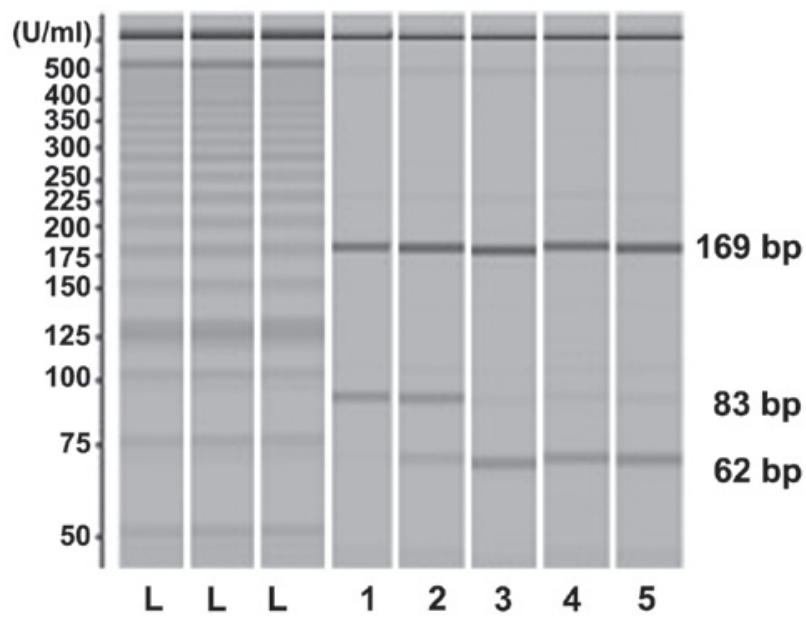

Figure 1. PCR-RFLP of the SRD5A2 polymorphism by MCEA $^{\circledR}-202$ MultiNA (Shimadzu, Japan). PCR-RFLP product samples: Lane L, 25 bp ladder; lane 1, LL allele; lane 2, VL allele; lanes 3-5, VV allele. PCR-RFLP, restriction fragment length polymorphism analysis polymerase chain reaction.

ments. The allelic variant SRD5A2-89L generated two bands of 83 and $169 \mathrm{bp}$ since the $R s a \mathrm{I}$ site was lost. The PCR-RFLP of the SRD5A2 polymorphism was analyzed by MCEA ${ }^{\circledR}-202$ MultiNA (Shimadzu, Japan) and the PCR-RFLP product samples are shown in Fig. 1.

Statistical analysis. Basic descriptive statistics and cross tabulations for frequencies with $\chi^{2}$ tests were performed. The measure of choice was the odds ratio (OR) with its corresponding 95\% confidence intervals (95\% CIs) that was used to determine the association between the SRD5A2 gene polymorphism and prostate cancer. All the data were analyzed with SPSS software (version 19.0; SPPS Inc., Chicago, IL, USA). $\mathrm{P}<0.05$ was considered to indicate a statistically significant difference and all the P-values presented are two-sided. The distribution of the genotypes in the control group was tested for the deviation from Hardy-Weinberg equilibrium (HWE) at the $\mathrm{P}<0.05$ level using an online tool for case-control studies (http://ihg.gsf.de/cgi-bin/hw/hwa1. $\mathrm{pl).}$

\section{Results}

Characteristics of the study population. Selected characteristics of the study population, which consisted of 260 patients with prostate cancer and 196 controls, are presented in Table I. The cases and controls were age-matched with a mean age of 63.6 years and 62.3 years, respectively. PSA level was measured in control group at the time of patient first visit. The mean serum PSA levels, measured at the time of diagnosis averaged to $27.39 \mathrm{ng} / \mathrm{ml}$ in the prostate cancer group and $1.05 \mathrm{ng} / \mathrm{ml}$ in the controls $(\mathrm{P}<0.001)$.

Genotype variants. The frequencies of the $\mathrm{V}$ and $\mathrm{L}$ allele in the controls were consistent with HWE (Pearson coefficient, $\mathrm{P}=0.266$ ); however, there was significant deviation of genotype distribution from HWE in the prostate cancer group (Pearson coefficient, $\mathrm{P}=0.037$ ) (data not shown).
Table I. Basic characteristics of the study population.

\begin{tabular}{lccc}
\hline Parameter & $\begin{array}{c}\text { Cases, } \\
\mathrm{n}=260\end{array}$ & $\begin{array}{c}\text { Controls, } \\
\mathrm{n}=196\end{array}$ & P-value $^{\mathrm{a}}$ \\
\hline Age, years & & & $\mathrm{NS}$ \\
Mean & 63.63 & 62.30 & \\
SD & 7.27 & 6.34 & \\
Median & 63.00 & 62.07 & \\
Min-max & $48-84$ & $52-76$ & \\
PSA, ng/ml & & & $<0.001$ \\
Mean & 27.39 & 1.05 & \\
SD & 69.59 & 0.77 & \\
Median & 9.34 & 0.81 & \\
Min-max & $1.87-810.5$ & $0.17-3.90$ & \\
Gleason score, $\mathrm{n}(\%)$ & & & \\
$<7$ & $83(31.9)$ & NA & - \\
$\geq 7$ & $159(61.2)$ & NA & - \\
Unknown & $18(6.9)$ & NA & - \\
\hline
\end{tabular}

aDetermined by the Mann-Whitney test. SD, standard deviation; NS, not significant; NA, not applicable; PSA, prostate-specific antigen.

Table II. Distribution of the SRD5A2 genotype variants.

\begin{tabular}{lrccc}
\hline $\begin{array}{l}\text { Genotype/ } \\
\text { allele }\end{array}$ & $\begin{array}{c}\text { Cases, } \\
\mathrm{n}(\%)\end{array}$ & $\begin{array}{c}\text { Controls, } \\
\mathrm{n}(\%)\end{array}$ & $\begin{array}{c}\text { OR } \\
(95 \% \mathrm{CI})\end{array}$ & P-value \\
\hline $\mathrm{VV}$ & $97(37.3)$ & $73(37.2)$ & 1.00 (reference) & - \\
$\mathrm{VL}$ & $110(42.3)$ & $87(44.4)$ & $0.95(0.63-1.44)$ & $\mathrm{NS}$ \\
$\mathrm{LL}$ & $53(20.4)$ & $36(18.4)$ & $1.11(0.66-1.86)$ & $\mathrm{NS}$ \\
VL+ LL & $163(62.7)$ & $123(62.8)$ & $0.99(0.68-1.46)$ & $\mathrm{NS}$ \\
Allele V & $304(58.5)$ & $233(59.4)$ & $1.00($ reference) & - \\
Allele L & $216(41.5)$ & $159(40.6)$ & $1.04(0.80-1.36)$ & $\mathrm{NS}$ \\
\hline
\end{tabular}

SRD5A2 genotype variants resulting from a polymorphism at codon 89 in the study cohort and corresponding ORs for developing prostate cancer. NS, not significant. OR, odds ratio.

The frequencies of the V89L genotype variants and the correspondent ORs $(95 \% \mathrm{CI})$ for the risk of prostate cancer development that are valid for particular allele variants are listed in Table II. The difference in distribution of three genotype variants resulting from the polymorphism at codon 89 between the case and control groups was not statistically significant ( $\chi^{2}$ test, $\mathrm{P}=0.842$ ). There was no significant allelic or genotypic association between the SDR5A2 V89L polymorphism and the risk of developing prostate cancer. Males with the VL genotype had a 0.95 -fold reduction in the risk of developing prostate cancer (95\% CI 0.63-1.44), the LL genotype was associated with a 1.11-fold increased risk of developing prostate cancer (95\% CI 0.66-1.86) and the VL + LL genotype with a 0.99 -fold reduced risk of developing prostate cancer (95\% CI 0.68-1.46) when compared with the VV genotype. 
Table III. Gleason score in patients with prostate cancer with SRD5A2 genotypes $(\mathrm{n}=242)$.

\begin{tabular}{lcrcr}
\hline & \multicolumn{2}{c}{ No. of cases (\%) } & & \\
\cline { 2 - 3 } Genotype/allele & Gleason $<7$ & Gleason $\geq 7$ & OR (95\% CI) & P-value \\
\hline VV & $31(37.3)$ & $59(37.1)$ & 1.00 (reference) & - \\
VL & $37(44.6)$ & $73(45.9)$ & $1.04(0.58-1.86)$ & NS \\
LL & $15(18.1)$ & $27(17.0)$ & $0.95(0.44-2.04)$ & NS \\
VL + LL & $52(62.7)$ & $100(62.9)$ & $1.01(0.58-1.76)$ & NS \\
Allele V & $99(59.6)$ & $191(60.1)$ & 1.00 (reference) & NS \\
Allele L & $67(40.4)$ & $127(39.9)$ & $0.98(0.67-1.44)$ & N \\
\hline
\end{tabular}

NS, not significant. OR, odds ratio; CI, confidence interval.

Analysis according to the Gleason score. An analysis according to the Gleason score and the SRD5A2 V89L polymorphism was performed in 242 patients with prostate cancer (Table III). No significant difference was identified in the frequencies of genotype variants with respect to tumor aggressiveness according to the Gleason score $\left(\chi^{2}\right.$ test, $\mathrm{P}=0.971$ ). Therefore, no significant increase in OR for developing highly aggressive prostate cancer for any particular genotype variant was identified when compared with the wild type VV variant (ORs ranged from 0.95-1.04, $\mathrm{P}>0.05$ ).

Additionally, no significant difference was identified in the genotype distribution leading to an increased or decreased risk of developing prostate cancer regardless of the age of disease onset when comparing LL and VV variants (under and over 65 years of age) with $\mathrm{OR}=1.09$ (95\% CI 0.57-2.09, P>0.05) and $\mathrm{OR}=1.08$ (95\% CI 0.43-2.72, $\mathrm{P}>0.05$ ), respectively (data not shown). Considering 65 years of age as early onset of disease, no difference in genotype distribution leading to early onset of prostate cancer with comparable OR for LL and VV variants was observed $(\mathrm{OR}=1.09,95 \% \mathrm{CI} 0.57-2.09, \mathrm{P}>0.05$ and $\mathrm{OR}=1.08,95 \%$ CI $0.43-2.72, \mathrm{P}>0.05$, respectively) (data not shown).

\section{Discussion}

Androgens are critical in prostate gland growth and prostate cancer development. It has been hypothesized that variation in the genes involved in androgen biosynthesis and metabolism may be a risk factor for prostate cancer. Genetic research has aimed to identify genetically determined differences in androgen metabolism, which may explain a number of the differences in the risk of prostate cancer $(35,36)$. Results of such studies, including clinical, epidemiological and biochemical research are presented with conflicting outcomes. SRD5A2 has long been considered as a strong candidate gene for prostate cancer development due to its key role in the androgen metabolism. Polymorphisms in the SRD5A2 gene have been investigated extensively. The V89L substitution mutation results in an almost $30 \%$ reduction in enzyme activity in vitro and in vivo when compared with the wild type gene (37). Thus, this polymorphism may alter the intraprostatic level and activity of DHT and consequently, the risk of prostate cancer.
To the best of our knowledge, this is the first study to investigate the association between prostate cancer risk and the functional polymorphism of the $S R D 5 A 2$ gene involved in the sex hormone pathways. The results do not indicate a significant effect of the SRD5A2 V89L polymorphism on the risk of developing prostate cancer. Allele frequencies of the SRD5A2 gene follow diverse ethnicity and/or geography-specific patterns. According to data from the SNP database (38), the frequency of the leucine allele ranges from $19-23 \%$ in North American and European Caucasian populations and 40-50\% in Asians. Correspondingly, the LL phenotype frequency is low in Caucasians (3-6\%) and higher in Asians (27-30\%) (20). The prevalence rate of VL heterozygosity and LL homozygosity was 44.4 and $18.4 \%$, respectively, in the Caucasian control subjects. However, the distribution of genotypes in the control group was consistent with HWE.

The results of the present study are generally in agreement with the results of several published case-control studies and meta-analyses $(12,30,28)$. Li et al (28) conducted a meta-analysis of 31 studies with SRD5A2 genotyping in 14,726 patients with prostate cancer and 15,802 controls, revealed no association between prostate cancer risk and the $\mathrm{L}$ allele compared with the V allele with an OR of 1.02 (95\% CI 0.98-1.06, $\mathrm{P}=0.38$ ). Their results were consistent across regardless of race. This study also observed no association between the $\mathrm{L}$ allele and the risk of prostate cancer regardless of the grade of cancer. The results of the present study showed no changes in the risk of prostate cancer development for different allele variants (LL, VL, LL + VL) compared with the wild type VV variant (ORs ranged from 0.95-1.11).

Additionally, an earlier meta-analysis by Wang et al (30) indicated that the SRD $5 A 2$ V89L polymorphism only exhibited a low-penetrant role in prostate cancer risk among Europeans and individuals younger than 65 years. In Europeans the small increase in prostate cancer risk was observed in the dominant model (LL + VL vs. VV) with an OR of 1.11 (95\% CI, 1.03-1.19; $\mathrm{P}<0.01)$. A significant association with an increased prostate cancer risk in men aged 65 years was observed in codominant allelles, i.e. LL vs. VV (OR, 1.70; 95\% CI 1.09-2.66, $\mathrm{P}=0.02$ ) and recessive, i.e. $\mathrm{LL}$ vs. $\mathrm{VV}+\mathrm{VL}$ (OR, 1.75; 95\% CI, 1.14-2.68; $\mathrm{P}=0.01$ ) models. However, no significant associations were found in Asians and Africans or in the overall analysis. 
The exact role of androgens in the pathogenesis of prostate cancer has been a contentious issue; thus, serum hormone levels may not provide definitive proof for the presence or absence of a genetic predisposition to prostate cancer (17). Certain studies report associations between the SRD5A2 V89L polymorphism and plasma androgen levels, including testosterone and 5a-androstane-3a-17a-diol glucuronide (3a-diolG), which is a direct metabolite of DHT and may be an indicator of 5 - $\alpha$-reductase, type II activity $(22,39)$. It has been reported that males with the VL and LL genotypes in comparison with those with the VV genotype exhibited a lower serum level of 3a-diolG (22). Conversely, Hayes et al (40) found no evidence of association between the SRD5A2 V89L polymorphism and testosterone, androstenedione, sex hormone-binding globulin or circulating levels of $3 \mathrm{a}-\mathrm{diolG}$ and the risk of prostate cancer. The results of the study by Hayes et al (40) are concurrent with the results of the European Prospective Investigation into Cancer and Nutrition study performed in 2001 (41), which revealed that $S R D 5 A 2$ V89L was associated with changes in the serum androgen levels, while another SRD5A2 A49T polymorphism caused a $24 \%$ reduction of circulating levels of 3a-diolG in carriers of the GA genotype compared with the GG genotype, leading to a $60 \%$ higher risk of developing prostate cancer $(24,40)$.

The most significant clinical features of prostate cancer that influence the choice of treatment include the age of a patient at the time of diagnosis (early vs. late onset of disease) and prostate tumor aggressiveness. The best result of genotyping studies in an individual patient would be the ability to predict early onset of highly aggressive prostate cancer with establishment of an appropriate therapy. Scariano et al (20) genotyped 33 males with early onset prostate cancer and found that the expression of at least one SRD5A L allele in young males with prostate cancer was associated with a more significant disease at the time of presentation as was defined by the pretreatment PSA level, clinical staging and Gleason score when compared with affected subjects harboring the more common SRD5A2 V variant. Similar results were published by other studies $(34,42)$. Cicek et al (34) confirmed the association between the SRD5A2 polymorphism and increased risk of prostate cancer in males diagnosed at an earlier age or with more aggressive disease (OR, 2.35; 95\% CI, 1.41-3.92; $\mathrm{P}=0.001$ and OR, 1.63; 95\% CI, 0.98-2.72; $\mathrm{P}=0.06$, respectively). By contrast, in our cohort no significant difference was identified in the genotype distribution leading to increased risk of prostate cancer regardless of disease onset when comparing LL and VV variants (data not shown). The hypothesis that any allele variant can drive the development of high risk prostate cancer was not able to be proven. The cut-off value (equal to 7) for the Gleason score was selected with respect to the indubitable significance of such a value for clinical decision making in a treatment scenario. Results similar to ours, regarding the non-significant association between SRD5A2 V89L polymorphism and Gleason score are also presented in a meta-analysis published by Li et al (28).

The present study and results of previous studies do not clearly confirm the exact role of the SRD5A2 V89L polymorphism in prostate cancer susceptibility. This requires a complex approach and we hypothesized that the activity of 5- $\alpha$-reductase, type II can be affected not only by this and/or other polymorphisms, but also by: i) Changes in the expression of the $S R D 5 A 2$ gene; ii) differences in the local concentrations of growth factors and other androgens that are also involved in the regulation of this enzyme activity in vivo; and iii) environmental factors, such as diet that may also influence the androgen levels and may be partly mediated through the different activity of 5- $\alpha$-reductase, type II. In addition, circulating androgen levels are likely to be only weakly correlated with androgen levels within the prostate gland and can only provide a limited view of the complexity of physiological events that regulate 5 - $\alpha$-reductase, type II activity (41).

Furthermore, the etiology of such a multigenetic disease cannot be explained by allelic variability at a single locus and it is supposed that high throughput genotyping may aid in the identification of novel genes, which could be suitable targets for analysis in association studies.

\section{Acknowledgements}

This study was supported by the Ministry of Health of the Slovak Republic under the project 2007/45-UK-10 'Genetic polymorphism of xenobiotic metabolising enzymes and susceptibility to prostate cancer in the Slovak population' (grant no. MH SR 2007/57-UK-17). This study was supported by the 'Center of Excellence for Research on Personalized Therapy (CEVYPET)’ project, code 2622012053, co-financed from EU sources and the European Regional Development Fund. The authors would like to thank Mrs. M. Martinčeková for her technical assistance.

\section{References}

1. Grönberg H: Prostate cancer epidemiology. Lancet 361: 859-864, 2003.

2. Ondrušová $\mathrm{M}$ and Ondruš $\mathrm{D}:$ : The occurence and mortality from prostate cancer in Slovakia and abroad. Onkológia (Bratisl.) 4: 272-274, 2009. (In Slovak)

3. Plesko I, Obsitníkova A, Cuninkova M, Tomasek L, Stefanakova D and Kubik A: Increasing occurrence of urological cancers in Slovakia. Neoplasma 51: 248-254, 2004.

4. Khan N, Afaq F and Mukhtar H: Lifestyle as risk factor for cancer: evidence from human studies. Cancer Lett 293: 133-143, 2010.

5. Stein QP and Flanagan JD: Genetic and familial factors influencing breast, colon, prostate and lung cancers. S D Med: 16-22, 2010

6. Sánchez-Visconti G, Herrero L, Rabadán M, Pereira I and Ruiz-Torres A: Ageing and prostate: age-related changes in androgen receptors of epithelial cells from benign hypertrophic glands compared with cancer. Mech Ageing Dev 82: 19-29, 1995.

7. Brawley OW, Jani AB and Master V: Prostate cancer and race. Curr Probl Cancer 31: 211-225, 2007.

8. Sivonova MK, Dobrota D, Matakova T, Dusenka R, Grobarcikova S, et al: Microsomal epoxide hydrolase polymorphisms, cigarette smoking and prostate cancer risk in the Slovak population. Neoplasma 59: 79-84, 2012.

9. Imamoto T, Suzuki H, Utsumi T, Endo T, Takano M, et al: Association between serum sex hormone levels and prostate cancer: effect of prostate cancer on serum testosterone levels. Future Oncol 5: 1005-1013, 2009.

10. Heinlein CA and Chang C: Androgen receptor in prostate cancer. Endocr Rev 25: 276-308, 2004.

11. Van der Kwast TH, Schalken J, Ruizeveld de Winter JA, van Vroonhoven CC, et al: Androgen receptors in endocrine-therapy-resistant human prostate cancer. Int J Cancer 48: 189-193, 1991.

12. Li X, Huang Y, Fu X, Chen C, Zhang D, et al: Meta-analysis of three polymorphisms in the steroid-5- $\alpha$-reductase, $\alpha$ polypeptide 2 gene (SRD5A2) and risk of prostate cancer. Mutagenesis 26: 371-383, 2011. 
13. Wilbert DM, Griffin JE and Wilson JD: Characterization of the cytosol androgen receptor of the human prostate. J Clin Endocrinol Metab 56: 113-120, 1983.

14. Coffey DS: The Molecular Biology of the Prostate. In: Prostate Diseases. Lepor H and Lawson RK (eds) Saunders, Philadelphia, PA, pp28-56, 1993.

15. Ross RK, Bernstein L, Lobo RA, Shimizu FZ, Stanczyk FZ, et al: 5 - $\alpha$-reductase activity and risk of prostate cancer among Japanese and US white and black males. Lancet 339: 887-889, 1992.

16. Wu AH, Whittemore AS, Kolonel LN, John EM, Gallagher RP, et al: Serum androgens and sex-hormone binding globulins in relation tolifestyle factors in older African-American, white, and Asian men in the United States and Canada. Cancer Epidemiol Biomarkers Prev 4: 735-741, 1995.

17. Ntais C, Polycarpou A and Ioannidis JP: SRD5A2 gene polymorphisms and the risk of prostate cancer: a meta-analysis. Cancer Epidemiol Biomarkers Prev 12: 618-624, 2003.

18. Montgomery RB, Mostaghel EA, Vessella R, Hess DL, Kalhorn TF, et al: Maintenance of intratumoral androgens in metastatic prostate cancer: a mechanism for castration-resistant tumor growth. Cancer Res 68: 4447-4454, 2008.

19. Reichardt JK, Makridakis N, Henderson BE, Yu MC, Pike MC and Ross RK: Genetic variability of the human SRD5A2 gene: implications for prostate cancer risk. Cancer Res 55: 3973-3975, 1995.

20. Scariano JK, Treat E, Alba F, Nelson H, Ness SA and Smith AY: The SRD5A2 V89L polymorphism is associated with severity of disease in men with early onset prostate cancer. Prostate 68: 1798-1805, 2008.

21. Boger-Megiddo I, Weiss NS, Barnett MJ, Goodman GE and Chen CH: V89L polymorphisms of the $5 \alpha$-reductase Type II gene (SRD5A2), endogenous sex hormones, and prostate cancer risk. Cancer Epidemiol Biomarkers Prev 17: 286-291, 2008.

22. Hsing AW, Chen C, Chokkalingam AP, Gao YT, Dightman DA, et al: Polymorphic markers in the SRD5A2 gene and prostate cancer risk: a population-based case-control study. Cancer Epidemol Biomarkers Prev 10: 1077-1082, 2001.

23. Makridakis NM, di Salle E and Reichardt JK: Biochemical and pharmacogenetic dissection of human steroid 5a-reductase type II. Pharmacogenetics 10: 407-413, 2000.

24. Allen NE, Forrest MS and Key TJ: The association between polymorphisms in the CYP17 and 5 $\alpha$-reductase (SRD5A2) genes and serum androgen concentrations in men. Cancer Epidemiol Biomarkers Prev 10: 185-189, 2001.

25. Febbo PG, Kantoff PW, Platz EA, et al: The V89L polymorphism in the $5 \alpha$-reductase type 2 gene and risk of prostate cancer. Cancer Res 59: 5878-5881, 1999.

26. Giwercman YL, Abrahamsoon PA, Giwercman A, Gadaleanu V and Ahlgren G: The $5 \alpha$-reductase type II A49T and V89L high-activity allelic variants are more common in men with prostate cancer compared with the general population. Eur Urol 48: 679-685, 2005.

27. Berndt SI, Chatterjee N, Huang WY, et al: Variant in sex hormone-binding globulin gene and the risk of prostate cancer. Cancer Epidemiol Biomarkers Prev 16: 165-168, 2007.
28. Li J, Coates RJ, Gwinn M, Khoury MJ, et al: Steroid 5- $\alpha$-reductase Type 2 (SRD5A2) gene polymorphisms and risk of prostate cancer: a HuGE review. Am J Epidemiol 171: 1-13, 2010.

29. Schatzl G, Madersbacher S, Gsur A, et al: Association of polymorphisms within androgen receptor, $5 \alpha$-reductase, and PSA genes with prostate volume, clinical parameters, and endocrine status in elderly men. Prostate 52: 130-138, 2002.

30. Wang CH, Tao W, Chen Q, Hu H, Wen XY, et al: SRD5A2 V89L polymorphism and prostate cancer risk: Meta-analysis. The Prostate 70: 170-178, 2010.

31. Epstein JI, Allsbrook WC Jr, Amin MB, Egevad LL; ISUP Grading Committee: The 2005 International Society of Urological Pathology (ISUP) Consensus Conference on Gleason grading of prostatic carcinoma. Am J Surg Pathol 29: 1228-1242, 2005.

32. Deantoni EP: Age-specific reference ranges for PSA in the detection of prostate cancer. Oncology (Williston Park) 11: 475-482 and 485-486, 1997.

33. Ausubel F, Brent R, Kingston R, Moore D, Seidman JG, Smith J and Struhl K (eds.): Short Protocols in Molecular Biology 3rd edition, Unit 2.1: John Wiley \& Sons, New York, NY, pp2-3, 1995

34. Cicek MS, Conti DV, Curran A, Neville PJ, Paris PL, et al: Association of prostate cancer risk and aggressiveness to androgen pathway genes: SRD5A2, CYP17, and the AR. The Prostate 59: 69-76, 2004.

35. Lunn RM, Bell DA, Mohler JL and Taylor JA: Prostate cancer risk and polymorphism in 17 hydroxylase (CYP17) and steroid reductase (SRD5A2). Carcinogenesis 20: 1727-1731, 1999.

36. Ross RK, Bernstein L, Lobo RA, Shimizu H, Stanczyk FZ, et al: 5a-reductase activity and risk of prostate cancer among Japanese and U.S. white and black males. Lancet 339: 887-889, 1992.

37. Makridakis N, Ross RK, Pike MC, Chang L, Stanczyk FZ, et al: A prevalent missense substitution that modulates activity of prostatic steroid 5a-reductase. Cancer Res 57: 1020-1022, 1997.

38. Zeigler-Johnson CM, Walker AH, Mancke B, et al: Ethnic differences in the frequency of prostate cancer susceptibility alleles at SRD5A2 and CYP3A4. Hum Hered 54: 13-21, 2002.

39. Jiang J, Tang NL, Ohlsson C, Eriksson AL, Vandenput L, et al: Association of SRD5A2 variants and serum androstane-3 $\alpha$, 17beta-diol glucuronide concentration in Chinese elderly men. Clin Chem 56: 1742-1749, 2010.

40. Hayes VM, Severi G, Padilla EJD and Morris HA: $5 \alpha$-reductase type 2 gene variant associations with prostate cancer risk, circulating hormone levels and androgenetic alopecia. Int $\mathrm{J}$ Cancer 120: 776-780, 2006

41. Allen NE, Forrest MS and Key TJ: The association between polymorphisms in the CYP17 and 5alpha-reductase (SRD5A2) genes and serum androgen concentrations in men. Cancer Epidemiol Biomarkers Prev 10: 185-189, 2001.

42. Forrest MS, Edwards SM, Houlston R, Kote-Jarai Z, Key T, et al: Association between hormonal genetic polymorphisms and early-onset prostate cancer. Prostate Cancer and Prostatic Diseases 8: 95-102, 2005.

43. Allen NE, Reichardt JK, Nguyen H and Key TJ: Association between two polymorphisms in the SRD5A2 gene and serum androgen concentrations in British men. Cancer Epidemiol Biomarkers Prev 12: 578-81, 2003. 